\title{
PREVALENSI DAN INTENSITAS EKTOPARASIT PADA IKAN NILA (Oreocromis niloticus) YANG DIBERI PAKAN BUNGKIL KELAPA HASIL FERMENTASI DALAM WADAH TERKONTROL
}

\section{(Prevalence and Intensity of Ectoparasites of Tilapia (Oreocromis Niloticus) Fed Fermented Coconut Meals in Controlled Containers)}

\author{
oleh: \\ Harlina Harlina ${ }^{1)}$, St Hadijah $^{1)}$, Kamaruddin ${ }^{2)}$, Nurhidayah ${ }^{2)}$ dan Nurwahyudin ${ }^{3)}$ \\ 1) Program Studi Budidaya Perairan FPIK UMI \\ 2) Peneliti Balai Riset Budidaya Air Payau dan Penyuluhan Perikanan Maros \\ 3) Mahasiswa Program Studi Budidaya Perairan FPIK UMI \\ Korespondensi: 1inausman1965@yahoo.com
}

\section{Diterima: tanggal 5 September 2019; Disetujui 30 Oktober 2019}

\begin{abstract}
An ectoparasitic infection is one of the causes of losses for the farmers of red tilapia (Oreochromis niloticus). This study was aimed to determine the types of parasites, the level of attack includes the prevalence, intensity and dominance of ectoparasites in red tilapia by adding fermented copra meal to the feed. The research was carried out at the Maros Fish Farming Center, South Sulawesi, while observing parasites in fish were carried out at the BRBAPPP Fish Pathology and Health Laboratory, Maros. The treatments were tested by addition of fermented copra meal as follows: (A) $0 \%$ control; (B) $15 \%$; (C) $30 \%$ and (D) $45 \%$. The experimental feed was applied to the fish once a day by satiation. The parameters observed were 1) identification of parasites; 2) prevalence rate; 3) attack intensity; 4) dominance and 5) water quality. A total of 30 tilapia from containers were taken to observe the fish organs included, ectoparasites were observed using a smear method on the target organ (gills, scales and fins and eyes), then examined microscopically. The ectoparasites were identified based on Kabata (1985), Grabda (1981) and Moller and Anders (1986). The result found two types of parasites namely Argulus sp. and Epistylis sp. The result of the prevalence of Argulus sp. of treatments A, B, and D were obtained (3.33\%) and intensity (1 ind/fish) except that Treatment C was obtained prevalence and intensity $(0 \%)$. While the highest prevalence rate of Vorticella sp. in A (Control) was $20 \%$ (frequent infections) while other treatments were still relatively low at $3.33 \%$ $13.3 \%$ (sometimes infections) with intensity of attacks $0-1$ ind / fish (low infection rate). The dominance value in all treatments ranged from 0.1 to $0.85 \%$. The range of water quality of fish container were temperature $26.3-29.2^{\circ} \mathrm{C}, \mathrm{pH}$ 7.5-7.8, DO 5.8-6.4 ppm and ammonia 0.02-0.26 ppm. The value was within good range for Red Tilapia.
\end{abstract}

Keywords: Red Tilapia, Prevalence, Intensity, Ectoparasites, Copra Meal

\begin{abstract}
ABSTRAK
Infeksi ektoparasit merupakan salah satu penyebab kerugian bagi para pembudidaya ikan nila merah (Oreocromis niloticus). Penelitian ini bertujuan untuk mengetahui jenis-jenis parasit, tingkat serangan meliputi prevalensi, intensitasdan dominansi Ektoparasit pada pada ikan Nila Merah yang dipelihara dengan penambahan bungkil kopra yang telah difermentasi pada pakan. Penelitian ini dilaksanakan di Balai Budidaya Ikan Maros, Sulawesi Selatan, sedangkan pengamatan parasit pada ikan dilakukan di Laboratorium Patologi dan Kesehatan Ikan BRBAPPP, Maros. Perlakuan yang diujicobakan adalah penambahan tepung bungkil kopra yang sudah difermentasi sebagai berikut (A) Kontrol 0\%; (B) 15\%; (C) 30\% dan (D) 45\%. Ikan diberi pakan uji secara satiasi perhari dengan frekuensi 1 kali sehari. Parameter yang diamati adalah 1) Identifikasi parasit; 2) Tingkat Prevalensi; 3) Intensitas Serangan; 4) Dominansi dan 5) Kualitas air. Sebanyak 30 ekor ikan Nila dari wadah pemeliharaan diambil untuk diamati organ tubuh ikan meliputi. Pengamatan ektoparasit dilakukan dengan menggunakan metode smear pada organ target (insang, sisik dan sirip serta mata), kemudian diperiksa secara mikroskopis. Ektoparasit yang ditemukan kemudian diidentifikasi berdasarkan buku Kabata (1985), Grabda (1981) dan Moller dan Anders (1986). Berdasarkan hasil
\end{abstract}


pengamatan ditemukan 2 jenis parasit yaitu Argulus sp. dan Epistylis sp. Hasil pengamatan tingkat prevalensi Argulus pada perlakuan A, B, dan D diperoleh (3,33\%) dan intersitas (1 ind/ekor) kecuali Perlakuan $\mathrm{C}$ diperoleh Prevalensi dan Intersitas (0\%). Sedangkan tingkat Prevalensi Vorticella tertinggi pada A Kontrol sebesar $20 \%$ (infeksi sering) sementara perlakuan lainnya masih tergolong rendah yaitu 3,33\%- 13,3\% (infeksi kadang) dengan intensitas serangan 0-1ind/ekor (tingkat infeksi rendah). Adapun nilai dominansi pada semua perlakuan berkisar 0,1-0,85 \%. Hasil pengamatan kualitas air media pemeliharaan diperoleh nilai kisaran suhu $26,3-29,2{ }^{\circ} \mathrm{C}$, pH 7,5-7,8, oksigen 5,8-6,4 dan amoniak 0,02-0,26 ppm nilai tersebut masih berada pada kisaran yang layak untuk kehidupan ikan Nila Merah.

Kata kunci: Ikan Nila Merah, Prevalensi, Intensitas, Ektoparasit, Bungkil Kopra

\section{PENDAHULUAN}

Ikan nila (Oreochromis niloticus) merupakan salah satu komoditas perikanan yang digemari masyarakat dalam memenuhi kebutuhan protein hewani karena memiliki daging yang tebal serta rasa yang enak. Ikan nila juga merupakan ikan yang potensial untuk dibudidayakan karena mampu beradaptasi pada kondisi lingkungan dengan kisaran salinitas yang luas. Salah satu faktor kunci yang mempengaruhi keberhasilan dalam kegiatan budidaya ikan adalah pakan, dan kontribusinya dapat mencapai $70 \%$ dari total biaya produksi pada kegiatan budidaya intensif, terutama untuk biaya komponen protein pakan.

Masalah utama dalam usaha budidaya perikanan yang banyak dikeluhkan petani salah satunya adalah mahalnya harga pakan komersil. Pakan sebagai sumber energi untuk tumbuh merupakan komponen biaya produksi yang jumlahnya paling besar yaitu
40-89\% (Afrianto dan Evi, 2005). Selain itu, pakan komersil memiliki kandungan protein sekitar 26-30\%, sehingga jika manajemen pemberian pakan kurang baik maka dapat menyebabkan akumulasi bahan organik sehingga kadar amoniak tinggi yang mempercepat penurunan kualitas air ( Rohmana, 2009).

Salah satu faktor kegagalan budidaya perairan yang sering dihadapi adalah kematian yang disebabkan oleh serangan penyakit antara lain penyakit parasit yang menginfeksi ikan melalui berbagai media seperti air, manusia atau juga lewat peralatan budidaya (Purnomowati et al., 2002).

Parasit yang sering menyerang biota budidaya antara lain protozoa, metazoa, krustasea, dan hirudinea. Penyakit ikan muncul akibat ketidakserasian antara ikan sebagai inang patogen (mikro organisme penyebab penyakit) serta lingkungan (Post, 1987). Sistem pertahanan tubuh 
ikan dapat terganggu akibat adanya perubahan lingkungan serta berkembangnya patogen dalam suatu wadah budidaya.

Penyakit parasiter akan tumbuh subur pada kolam yang mengandung bahan organik yang tinggi yang terakumulasi di dasar perairan akibat sisa pakan yang tidak tercerna oleh ikan. Oleh karena itu penelitian ini penting untuk mengetahui kemungkinan aplikasi pakan yang ditambahkan bungkil kopra yang difermentasi dengan berbagai dosis terhadap tingkat serangan parasit pada ikan nila. Hasil penelitian ini penting sebagai data awal yang dapat dipertimbangkan dalam upaya pemgembangan budidaya ikan nila.

\section{METODE PENELITIAN}

Penelitian ini dilaksanakan pada bulan Maret sampai Juli 2019. Pelaksanaan penelitian dilakukan pada dua lokasi penelitian yaitu kegiatan pemeliharaan ikan di Balai Benih Ikan (BBI) Bantimurung, Kab. Maros Sulawesi Selatan. Sedangkan Pengamatan serangan penyakit dilakukan dengan mengidentifikasi jenis mikroorganisme penyebab penyakit, Prevalensi, intensitas dan Dominasi dilakukan di Laboratorium
Patologi dan Kesehatan Lingkungan Balai Riset dan Pengembangan Budidaya Air Payau dan Penyuluhan Perikanan, Maros Sulawesi Selatan

Wadah pemeliharaan yang digunakan berupa 12 akuarium kaca yang dilengkapi dengan sistem aerasi sebagai penyuplai oksigen. Wadah diisi dengan air tawar yang telah disucihamakan sebanyak 40 liter. Hewan uji yang digunakan adalah ikan nila merah ukuran rata-rata 0,2-0,5 g/ekor, ditebar dengan kepadatan 30ekor/akuarium.

Pakan yang digunakan adalah pakan komersil dengan penambahan bungkil kopra yang sdh difermentasi sesuai dengan dosis yang akan diujicobakan. Sebagai pakan kontrol digunakan pakan yang tanpa penambahan bungkil kopra. Ikan nila diberi pakan uji secara satiasi perhari dengan frekuensi 1 kali sehari pada pagi hari. Pakan komersil tersebut ditepungkan lalu ditambahkan tepung bungkil kopra hasil fermentasi sesuai dengan dosis perlakuan, kemudian dilakukan uji proksimat.

\section{Perlakuan yang Diujicobakan}

Pakan yang digunakan dalam penelitian ini adalah pakan komersil dengan penambahan bungkil kopra 
hasil fermentasi. Sebagai pakan kontrol digunakan pakan yang tanpa penambahan bungkil kopra. Adapun perlakuan yang diujicobakan adalah penambahan bungkil kopra yang telah difermentasi kedalam pakan dengan persentasi sebagai berikut: Perlakuan A: Pakan komersil tanpa tambahan bungkil kelapa yang tanpa fermentasi; Perlakuan B : penambahan $15 \%$; Perlakuan C: penambahan $30 \%$ dan Perlakuan D dengan penambahan $45 \%$.

\section{Pengamatan Ektoparasit}

Prosedur pengamatan ektoparasit adalah sebagai berikut: sampel ikan ditimbang beratnya dan diukur panjangnya dengan menggunakan mistar. Selanjutnya dibuat kerikan lendir pada semua filamen insang, sirip dan sisik. Hal ini sesuai dengan pernyataan Kabata (1985), bahwa kulit ikan seluruhnya dilindungi oleh lendir yang merupakan makanan yang baik bagi parasit dan kulit merupakan organ yang dapat dijadikan tempat hidup ektoparasit.

Hasil kerikan lendir dikumpulkan di dalam cawan petri. Kemudian dibuat cuplikannya di atas kaca objek dan dikeringanginkan. Selanjutnya cuplikan lendir difiksasi menggunakan metanol selama 15 menit. Lalu direndam dengan Giemsa 3\% selama 15-30 menit, dibilas dengan air dan dikeringkan dan diamati di bawah mikroskop. Parasit yang terlihat di bawah mikroskop cahaya difoto untuk diidentifikasi dan dibuat dokumentasinya. Identifikasi Ektoparasit Parasit yang ditemukan diidentifikasi menggunakan buku 'Parasite of Puerto Rican Freshwater Sport Fishes' Williams \& Williams (1994) dan buku' Parasites of Offshore Big Game Fishes of Puerto Rico and the Western Atlantic' Williams \& Williams (1996). Identifikasi parasit yang dijumpai dilakukan sampai tingkat genus.

\section{Analisis Data}

Data jenis dan jumlah parasit yang diperoleh dari hasil pemeriksaan, dianalisis secara deskriptif. Intensitas dan prevalensi ektoparasit dihitung dengan rumus sebagai berikut ini (Dogie et al. 1970):

Prevalensi dihitung menggunakan rumus:

$$
\text { Prevalensi }(\%)=\frac{\text { Jumlah ikan yang terserang parasite (ekor) }}{\text { Jumlah ikan yang diamati (ekor) }} x \quad 100 \%
$$

Intensitas ektoparasit menggunakan rumus: 


$$
\text { Intensitas }(I)=\frac{\text { Jumlah Parasit A yang menginfeksi }}{\text { Jumlah ikan yang terserang parasite }} x \quad 100 \%
$$

Dominansi dapat dihitung dengan rumus :

$$
\text { Dominansi }(\%)=\frac{\sum \text { Satu jenis ektoparasit yang menginfeksi ikan }}{\sum \text { Total ektoparasit yang menginfeksi ikan sampel }} x \quad 100 \%
$$

\section{Pengukuran Kualitas Air}

Parameter kualitas air yang diukur meliputi Suhu, Oksigen terlarut, Derajat keasaman $(\mathrm{pH})$, Amoniak. Pengukuran suhu, $\mathrm{pH}$ dan DO dilakukan di wadah pengamatan (in situ) sedangkan pengukuran konsentrasi Amoniak dilakukan di laboratorium Rekayasa Biota dan Lingkungan Fakultas Perikanan dan Ilmu kelautan UMI Makassar.

\section{HASIL DAN PEMBAHASAN}

\section{Identifikasi Jenis Ektoparasit yang menginfeksi Ikan Nila Merah}

Hasil pemeriksaan terhadap sampel ikan pada bagian sirip, bagian sisik dan insang menunjukkan bahwa teridentifikasi dua jenis ektoparasit, yaitu: Vorticella sp. dan Argulus sp. yang menginfeksi bagian sirip, bagian sisik dan insang. Sementara hasil penelitian yang telah dilakukan oleh Lianda et al., 2015 menemukan parasit yang paling banyak menginfeksi ikan nila di irigasi Barabung Kecamatan Darussalam Kabupaten Aceh Besar adalah Dactilogyrus sp. yang berpredileksi pada insang, Gyrodactylus yang berpredileksi pada sirip dan sisik, Camallanus yang ditemukan di dalam usus, dan $P$. nagpurensis yang berpredileksi pada usus. Hal ini menunjukkan bahwa ikan nila tidak luput dari berbagai macam serangan parasit.

Deskripsi jenis parasite yang menginfeksi ikan nila yang diberi pakan dengan penambahan bungkil kelapa sawit yang telah difermentasi adalah sebagai berikut:

\section{a. Vorticella sp.}

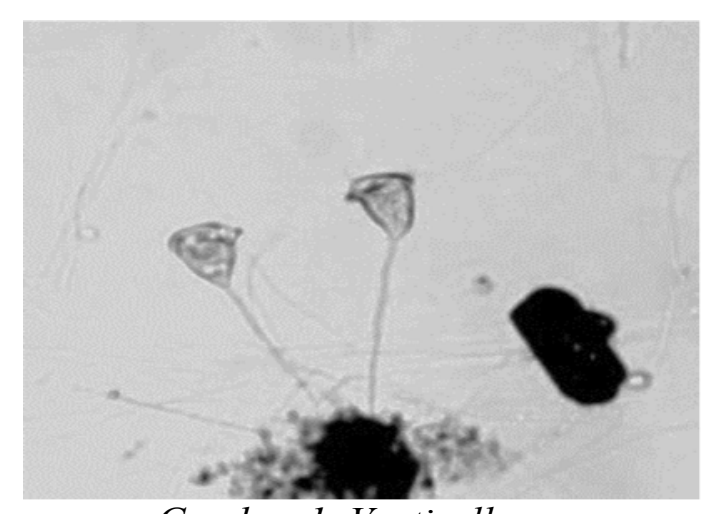

Gambar 1. Vorticella sp.

Vorticella sp. termasuk ke dalam: Kingdom : Animalia, Filum : Ciliophora, Kelas

Oligohymenophorea, Ordo 
Peritrichida (Sessilina) Famili : ikan air tawar, Vorticella sp. Juga Vorticellidae, Genus : Vorticella, merupakan epibion pada krustase Spesies : Vorticella sp. (Kabata, 1985). (Estrada, 2003), Dilaporkan bahwa Menurut Fernando et al. (1972) setiap bahwa genus Zoothamnium, Epistylis, jenis parasit mempunyai habitat yang berbeda pada organ inang sebagai tempat hidupnya, namun ada beberapa ektoparasit yang menginfeksi dua atau lebih organ tubuh inangnya, seperti Trichodina sp. yang dapat menginfeksi sisik, kulit, sirip dan insang.

Vorticella sp. ditemukan menginfeksi benih ikan nila merah. Parasit tersebut memiliki sel berwarna kehijauan, memiliki tangkai kontraktil, peristome besar dan bersilia, memiliki makronukleus serta mikronukleus. Zooid berbentuk lonceng terbalik terdiri dari tangkai berbentuk seperti bunga bersilia mengandung fibril disebut myoneme untuk menempel pada inang. Reproduksi parasit tersebut secara aseksual dengan cara pembelahan.

Vorticella sp. termasuk ke dalam parasit yang bersifat soliter dan perairan dengan bahan organik tinggi akan menguntungkan parasit ini untuk berkembang biak.Lebih lanjut AbdelBaki et al. (2014) menyatakan bahwa Vorticella sp. termasuk ektoparasit yang dapat menyebabkan kematian pada ikan. Selain ditemukan menyerang Vorticella sp. umumnya ditemukan menginfeksi udang yang dapat menyebabkan hipoksia dan kematian.

\section{b. Argulus sp.}

Ukuran Argulus sp. yang didapatkan pada penelitian ini memiliki panjang 0,3 cm. Jasminandar, (2011) menemukan argulus yamh menyerang pada ikan nila merah berukuran panjang 0,2-0,5 cm menginfestasi ikan pada bagian kulit atau sirip.

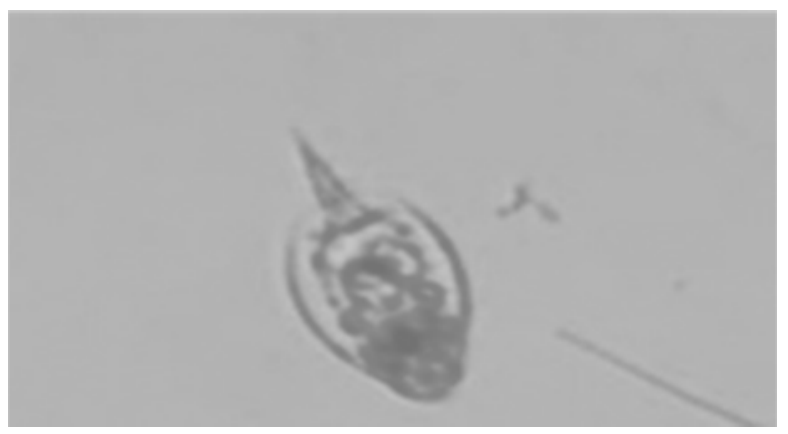

Gambar 2. Argulus sp.

Berdasarkan klasifikasi Argulus sp.termasuk ke dalam Phylum Arthropoda, Sub Phylum Crustacea Class Maxillopoda, Sub Class Branchiura, Ordo Arguloida, Family Argulidae, Genus Argulus, Spesies Argulus sp. Puspitasari et al., (2010). Argulus sp. merupakan parasit ikan dari golongan udang-udangan keluarga Branchiura. Parasit ini masuk ke dalam 
akuarium biasanya melalu pakan hidup. Diketahui ada sekitar 30 spesies Argulus. Dua diantaranya, yang erat kaitannya dengan akuarium, adalah Argulus foliaclus dan Argulus sp. japonicus (Puspitasari et al., 2010). Zulaeha et al., (2012), menyatakan bahwa Argulus sp. adalah salah satu jenis parasit terbesar yang dapat dilihat dengan mata telanjang karena ukurannya antara 5 sampai $10 \mathrm{~mm}$, Menurut Jasminandar, (2011), parasit Argulus biasanya menginfestasi ikan pada bagian kulit atau sirip dan dapat menimbulkan lubang kecil yang akhirnya dapat menimbulkan infeksi yang disebabkan bakteri dan jamur

Parasit ini memiliki tubuh rata oval mirip kuku, yang hampir seluruhnya ditutupi oleh karapas lebar, mata majemuk menonjol, dan antenna yang termodifikasi membentuk mulut, memiliki belalai berduri yang digunakan sebagai senjata untuk mengisap darah ikan sehingga ikan akan menjadi kurus. memiliki dua pasang toraks, yang digunakan untuk berenang antara inang yang berbeda. Argulus sp. merupakan ancaman yang sangat serius bagi kesehatan ikan, karena dapat menyebabkan mortalitas yang tinggi. Ikan yang terinfeksi biasanya terdapat bercak perdarahan dan kulit terjadi pembengkakan disekitar insang atau sirip.

Argulus sp. memiliki 2 mata majemuk untuk mendeteksi inang. Warna terang pada betina untuk perilaku penyerangan pada waktu gelap sehingga bisa berenang dan mencari makan sampai 4 kali lebih jauh. Pada waktu gelap, ikan tidak bisa berenang cepat hal ini memudahkan Argulus sp. Betina secara umum meletakan telur pada benda yang mengapung, secara tunggal, dobel maupun tripel, setelah itu kembali menyerang. Argulus sp. dapat dilihat dengan mata biasa (tanpa bantuan alat pembesar), di permukaan tubuh ikan inang seperti bulatanbulatan. Pertama kali menempel warnanya transparan kemudian lamakelamaan menjadi gelap atau seperti mata ular.

Ikan merupakan inang perantara dalam siklus hidup Argulus sp. Parasit ini menginfeksi ikan air tawar maupun ikan laut. Argulus sp. merupakan ektoparasit ikan yang menyebabkan penyakit argulosis. Dalam siklus hidupnya Argulus sp. menghabiskan sebagian besar waktu hidupnya dengan berenang di sekitar inangnya hingga terjadi perkawinan antara jantan dan 
betina. Telur yang sudah dibuahi selanjutnya akan terendam secara aman dalam sisik ikan dan setelah menetas Argulus sp. tersebut akan bermetamorfosis menuju dewasa. Seluruh siklus memakan waktu antara 3-10 hari tergantung pada suhu. Setelah menetas mereka harus menemukan inang baru dalam sekitar 4 hari atau akan mati (Zulaeha et al., 2012). Parasitik Argulus sp. Memiliki sifat yang cenderung temporer yaitu mencari inangnya secara bebas dan dapat berpindah dengan pada tubuh ikan lain atau bahkan meninggalkannya. Hal ini dapat dilakukan karena Argulus sp. mampu bertahan hidup selama beberapa hari di luar inang (Zulaeha et al., 2012). Parasit ini masuk ke dalam tempat pemeliharaan dan menginfeksi ikan biasanya melalui pergesekan antar kulit ikan yang terinfeksi Argulus sp. Menurut Zulaeha et al., (2012), menambahkan bahwa serangan parasit lebih sering mematikan pada ikan-ikan muda yang biasanya berukuran kecil karena sistem pertahanan tubuhnya belum berkembang.

Argulus sp. memiliki alat penghisap khusus sehingga dapat menempel pada ikan . Tingkat serangan Argulus sp. Sangat tergantung pada ukuran ikan dan jumlah individu parasit yang menyerang. Meskipun demikian Argulus sp. tidak menimbulkan ancaman kematian pada ikan bersangkutan. Akan tetapi luka yang ditimbulkannya dapat menjadi rentan terhadap jamur dan bakteri. Pada serangan yang sangat parah ikan dapat kehilangan banyak darah atau juga mengalami stress sosmotik akibat luka luka yang tidak tertutup dapat berakibat pada kematian.

\section{Prevalensi, Intensitas dan Dominasi Ektoparasit pada Ikan Nila Merah `(O. niloticus) \\ Prevalensi, Intensitas dan}

Dominasi ektoparasit yang menyerang ikan nila merah (O. niloticus) disajikan pada Tabel 1. 
Tabel 1. Nilai Prevalensi, Intensitas, dan Dominasi Ektoparasit pada Ikan Nila Merah (O. niloticus) Selama Penelitian.

\begin{tabular}{|c|c|c|c|c|c|c|}
\hline $\begin{array}{c}\text { Perlak } \\
\text { uan }\end{array}$ & $\begin{array}{c}\sum \text { Ikan } \\
\text { Di } \\
\text { Periksa }\end{array}$ & Jenis Parasit & $\begin{array}{c}\sum \text { Ilkan } \\
\text { Terseran } \\
\text { g }\end{array}$ & $\begin{array}{l}\text { Prevalen } \\
\text { si }(\%)\end{array}$ & $\begin{array}{c}\text { Intensitas } \\
\text { (Ind/Ekor } \\
\text { ) }\end{array}$ & $\begin{array}{c}\text { Dominas } \\
\mathrm{i} \\
(\%)\end{array}$ \\
\hline \multirow[b]{2}{*}{ A } & \multirow[b]{2}{*}{30} & Vorticella sp. & 6 & 20 & 1 & 0,85 \\
\hline & & Argulus sp. & 1 & 3,33 & 1 & 0,14 \\
\hline \multirow[b]{2}{*}{ B } & \multirow[b]{2}{*}{30} & Vorticella sp. & 1 & 3,33 & 1 & 0,5 \\
\hline & & Argulus sp & 1 & 3,33 & 1 & 0,1 \\
\hline \multirow[b]{2}{*}{$\mathrm{C}$} & \multirow[b]{2}{*}{30} & Vorticella sp & 3 & 10 & 1 & 0,1 \\
\hline & & Argulus sp. & 0 & 0 & 0 & 0 \\
\hline \multirow[b]{2}{*}{$\mathrm{D}$} & \multirow[b]{2}{*}{30} & Vorticella sp. & 4 & 13,33 & 1 & 0,8 \\
\hline & & Argulus sp. & 1 & 3,33 & 1 & 0,2 \\
\hline
\end{tabular}

Untuk menetapkan tingkat serangan berdasarkan Kriteria Prevalensi dan Intensitas serangan parasite mengacu menurut Williams, (1996)

Tabel 2. Kriteria Prevalensi Infeksi Parasit (menurut William, 1996)

\begin{tabular}{clcc}
\hline No & Tingkat serangan & Keterangan & Prevalensi \\
\hline 1 & Selalu & Infeksi sangat parah & $100-99 \%$ \\
2 & Hampir selalu & infeksi parah & $95-90 \%$ \\
3 & Biasanya & Infeksi sedang & $89-70 \%$ \\
4 & Sangat sering & Infeksi sangat sering & $69-50 \%$ \\
5 & Umumnya & Infeksi biasa & $49-30 \%$ \\
6 & Sering & Infeksi sering & $29-10 \%$ \\
7 & Kadang & Infeksi kadang & $9-1 \%$ \\
8 & Jarang & Infeksi jarang & $>1-0,1 \%$ \\
9 & Sangat jarang & Infeksi sangat jarang & $>0,1-0,01 \%$ \\
10 & Hampir tidak pernah & Infeksi tidak pernah & $>\mathrm{p} 0,01 \%$ \\
\hline
\end{tabular}

Tabel 3. Kriteria Intensitas menurut William, (1996).

\begin{tabular}{clc}
\hline No & \multicolumn{1}{c}{ Tingkat infeksi } & Intensitas (ind/ekor) \\
\hline 1 & Sangat rendah & $<1$ \\
2 & Rendah & $1-5$ \\
3 & Sedang & $6-55$ \\
4 & Parah & $51-100$ \\
5 & Sangat parah & $>100$ \\
6 & Super infeksi & $>1000$ \\
\hline
\end{tabular}

Tinggi rendahnya nilai prevalensi, intensitas dan dominasi parasit pada setiap perlakuan dipengaruhi oleh factor internal dan factor eksternal. Factor eksternal tersebut antara lain parameter kualitas air, yang diakibatkan 
oleh pencemaran di sekitar perairan baik limbah rumah tangga maupun limbah pertanian. Pencemaran lingkungan perairan akan mengakibatkan perubahan kualitas air dan meningkatkan jumlah pathogen seperti parasit, kondisi tersebut akan membuat ikan stress sehingga terjadinya hubungan yang tidak seimbang antara ikan, lingkungan, dan pathogen (parasite).

Berdasarkan dari tabel tersebut di atas dapat dilihat jumlah sampel pada masing-masing perlakuan sebanyak 30 ekor, kemudian hasil prevalensi, intensitas dan dominasi terlihat bahwa prevalensi pada perlakuan A untuk jenis parasit Vorticella sp. yaitu $20 \%$, hasil intensitas 1 (ind/ekor) dan untuk dominasi $85 \%$ sedangkan untuk jenis parasit argulus $\mathrm{sp}$ terlihat jumlah prevalensi 3,33\%, hasil intensitas 1 (ind/ekor) dan untuk dominasi $0,14 \%$. Pada perlakuan B untuk jenis parasit Vorticella sp. menunjukkan hasil prevalensi $3,33 \%$, hasil intensitas 1 (ind/ekor) dan untuk dominasinya $0,5 \%$ sedangkan untuk jenis parasit Argulus sp. untuk hasil prevalensi 3,33\%, hasil intensitas 1 (ind/ekor) dan untuk dominasi 0,1 . Kemudian untuk perlakuan $\mathrm{C}$ menunjukkan bahwa hasil prevalensi senilai 3,33\%, hasil intensitas 1 (ind/ekor) dan dominasi 0,1\%. Pada perlakuan D hasil prevalensi untuk parasit Vorticella sp. yang didapatkan yaitu 13,33\%, hasil intensitas 1 (ind/ekor) dan dominasi $0,8 \%$ sedangkan untuk hasil prevalensi untukparasit Argulus sp. di dapatkan yaitu 3,33\%, hasil intensitas $1 \%$ dan hasil dominasi yaitu $0,2 \%$.

\section{Kualitas Air}

Selama penelitian berlangsung, dilakukan pengukuran beberapa parameter kualitas air yang terdiri atas suhu, $\mathrm{pH}$, oksigen dan terlarut. Adapun data hasil pengukuran kualitas air disajikan dalam Tabel 4 sebagai berikut:

Tabel 4. Kisaran Parameter Kualitas Air Media Pemeliharaan Ikan Nila Merah

\begin{tabular}{lcll}
\hline \multicolumn{1}{c}{ Parameter } & Kisaran & \multicolumn{1}{c}{ Rujukan } \\
\hline Suhu $\left({ }^{0} \mathrm{C}\right)$ & $24,5-30^{\circ} \mathrm{C}$ & $25-32^{0} \mathrm{C}(\mathrm{BSN}, 2009)$ \\
Derajat Keasaman $(\mathrm{pH})$ & $6,9-7,8$ & $7-8(\mathrm{Cahyono})$ & \\
Oksigen terlarut $(\mathrm{ppm})$ & $4,1-7,3 \mathrm{ppm}$ & $3-4(\mathrm{Boyd}, 2004)$ & \\
Amoniak & $0,01-0,30 \mathrm{mg} . \mathrm{L}$ & $<0,02$ & mg.L \\
& & $(\mathrm{BSNI}, 2009)$ & \\
\hline
\end{tabular}


Sumber air yang digunakan adalah air tawar yang berasal dari Balai Benih Ikan Bntimurung. Air yang digunakan selama pemeliharaan benih ikan nila didukung dengan diterapkan sistem aerasi selama 24 jam, selain itu juga dilakukan pembersihan dasar wadah dengan cara dishipon. Penyiphonan dilakukan setiap pagi hari untuk mengambil sisa pakan yang tidak dimakan oleh ikan nila merah tersebut, Kegiatan pergantian air dilakukan setelah proses pengukuran panjang dan berat, dengan cara membuang 50\% dari total air yangada diwadah pemeliharaan kemudian menambahkan dengan air baru.

Berdasarkan data hasil penelitian pada Tabel 4 menunjukkan bahwa nilai suhu yang didapat selama penelitian berkisar antara $24,5-30^{\circ} \mathrm{C}$. Suhu mempengaruhi aktivitas, nafsu makan, konsumsi oksigen, dan laju metabolisme organisme. Nilai suhu yang didapat selama penelitian menunjukkan bahwa suhu selama penelitian masih dalam kondisi optimal untuk kelangsungan hidup serta pertumbuhan ikan nila. Suhu yang optimum untuk pemeliharaan ikan nila di kolam berkisar $25-32^{\circ} \mathrm{C}$.
Derajat keasaman air $(\mathrm{pH})$ selama pemeliharaan berkisar antara 6,9-7,8. Menurut Boyd (1990) mengemukakan bahwa $\mathrm{pH}$ yang didefenisikan sebagai logaritma dari aktivitas ion hydrogen ($\log \mathrm{H}^{+}$), merupakan indicator keasaman serta kebasaan air. Kuntinyo et al., (1994) mengemukakan bahwa agar pertumbuhan maksimal, kepiting sebaiknya dibudidayakan pada media dengan $\mathrm{pH}$ antara 7,5 dan 8,5. Derajat keasamaan $(\mathrm{pH})$ air dalam pertumbuhan ikan. Derajat keasaman air yang sangat rendah atau sangat asam dapat menyebabkan kematian ikan dengan gejala geraknya tidak teratur, tutup ingsang bergerak sangat aktif dan berenang sangat cepat di permukaan air. Keadaan air yang sangat basa dapat menyebabkan pertumbuhan ikan terhambat. Kisaran derajat kemasaman air untuk Usaha budidaya perairan berkisar 6,5 - 9,0 (Kordi dan Tancung, 2005).

Keperluan organisme air terhadap oksigen tergantung pada jenis, umur,dan aktivitasnya. Pada umur muda keperluan oksigen relatif lebih besar dibandingkan yang berumur lanjut (Kordi, 2010). Konsentrasi oksigen terlarutbukan merupakan faktor pembatas utamauntuk ikan nila, karena 
mereka dapat mentolerir tingkat serendah 3-4 mg/l (Boyd, 1990). Kandungan oksigen terlarut selama penelitian berkisar antara 4,1-7,3. Dari hasil pengamatan selama penelitian ketiga parameter yang diukur masih termasuk dalam kisaran optimal atau kisaran yang baik untuk pemeliharan ikan nila merah tetapi ada pula kendala yang terjadi dalam warna air yaitu terjadinya perubahan warna air yang keruh diakibatkan oleh feses dan sisa pakan, hal ini mengakibatkan tingginya amoniak diawal penelitian tetapi ditanggulangi dengan melakukan pergantian air secara keseluruhan. Hal ini membuktikan bahwa perbedaan hasil dari setiap perlakuan dipengaruhi oleh kondisi lingkungan dan pemberian dosis bungkil kopra fermentasi yang berbeda pada pakan yang akan diberikan pada ikan nila merah.

\section{KESIMPULAN}

Berdasarkan hasil pengamatan ektoparasit pada ikan nila merah yang dipelihara dengan penambahan bungkil kelapa yang telah difermentasi pada pakan di wadah terkontrol, disimpulkan bahwa terdapat dua jenis ektoparasit yang menginvasi ikan nila merah yaitu Vorticella sp. dan Argulus

sp. Invasi ektoparasit terbesar adalah dari genus Vorticella. Pada perlakuan control (pakan tanpa fermentasi) menunjukkan tingkat prevalensi Vorticella sp tertinggi sebesar yaitu $20 \%$, dengan intensitas 1 (ind/ekor) dan dominasi $85 \%$ sedangkan untuk jenis parasit argulus sp terlihat jumlah prevalensi 3,33\%, dengan intensitas 1 (ind/ekor) dan untuk dominasi $0,14 \%$. Pada perlakuan B untuk jenis parasit Vorticella menunjukkan hasil prevalensi 3,33\%, hasil intensitas 1 (ind/ekor) dan untuk dominasinya $0,5 \%$ sedangkan untuk jenis parasit Argulus sp. untuk hasil prevalensi 3,33\%, hasil intensitas 1 (ind/ekor) dan untuk dominasi 0,1. Kemudian untuk perlakuan $\mathrm{C}$ menunjukkan bahwa hasil prevalensi senilai 3,33\%, hasil intensitas 1 (ind/ekor) dan dominasi 0,1\%. Pada perlakuan D hasil prevalensi untuk parasit Vorticella sp. yang didapatkan yaitu 13,33\%, hasil intensitas 1 (ind/ekor) dan dominasi $0,8 \%$ sedangkan untuk hasil prevalensi untukparasit Argulus sp. di dapatkan yaitu 3,33\%, hasil intensitas $1 \%$ dan hasil dominasi yaitu $0,2 \%$. Dengan demikian pemberian pakan dengan penambahan bungkil kelapa yang difermentasi sebesar $35 \%$ lebih efektif 
menekan tingkat serangan parasite pada ikan nila merah

\section{SARAN}

Berdasarkan hasil penelitian tingkat serangan ektoparasit pada ikan nila merah yang dipelihara dengan penambahan bungkil kelapa yang telah difermentasi maka disarankan dalam pemeliharaan ikan nila sebaiknya menggunakan pakan dengan penambahan bungkil kopra hasil fermentasi $35 \%$.

\section{UCAPAN TERIMA KASIH}

Tulisan ini merupakan bagian dari penelitian Unggulan Internal yang dibiayai Universitas Muslim Indonesia melalui Lembaga Penelitian dan Pengembangan Sumberdaya Manusia (LP2S), terkait hal tersebut maka penulis mengucapkan terima kasih kepada Ketua LP2S dan Yayasan wakaf UMI Makassar yang telah membiayai penelitian ini pada tahun anggaran 2019.

\section{DAFTAR PUSTAKA}

Abdel-Baki, Gewik MM, Al-Quraishy S. 2014. Fish Records of Ambiphyra and Vorticella spp. (protozoa, Ciliophora) in cultured Nile tilapia Oreocromis niloticus I $n$ the central region of Saudi Arabia. Saudi journal of biological science. 21:520-523.

Afrianto dan Evi, 2005. Pengendalian Penyakit pada Ikan Nila. Kanasius. Jokjakarta

Boyd, C.E. 1990. Water Quality in Ponds for Aquaculture. Alabama Agriculture Experiment Station, Auburn University. Birmingham Publishing Co. Alabama. 482 hlm.

Dogie, V.A., G.K. Petrushevski and

I. Polyanski.1970.

Parasitologi of Fishes.

T.F.H. Publisher. Hongkong. $384 \mathrm{hlm}$.

Estrada RM. 2003. Protozoa parasite. Stoneville, Carolina (US): SRAC Publication. No.4701. FAO (food and agricultural organization. 2007. Assessment of freshwater fish seed resources for sustainable aquaculture. $507 \mathrm{p}$.

Kabata, Z. 1985. Parasites and Diseases of Fish Cultured in the Tropics. Taylor and Francis. London.

Kordi G. 2010. Budidaya Ikan Nila.

Dahara Prize. Semarang.

Kordi G, dan Tancung AB. 2005. Pengelolaan Kualitas Air Dalam Budidaya Perairan. Rineke Cipta. Jakarta.

Kuntinyo, Z. Arifin, dan T. Supratomo. 1994. Pedoman Budidaya Kepiting Bakau (Scylla serrata) di Tambak. Direktorat Jendral Perikanan, Balai 
Budidaya Air Payau, Jepara. 29 hlm.

Lianda, N., Y. Fahrimal, R., Daud, Rusli, Dwinna Aliza, dan Mulyadi Adam. 2015.

Identifikasi Parasit Pada Ikan Nila (Oreochromis Niloticus) Di Irigasi Barabung Kecamatan Darussalam Aceh Besar

Purnowawati, R. J. Dewi dan P. Hartono. 2002. Penyakit Parasit. Pengelolaan Kesehatan Ikan Budidaya Laut. Lampung.

Puspitasari. P, Faradilla P, Silvi I. K, Jeny Ernawati T. (2010). Usulan Program Kreatifitas Mahasiswa Efektivitas Penggunaan Probiotik Air Untuk Menghindari Investasi Argulus sp. Pada Ikan Mas (Cyprinus carpio). Universitas Airlangga. Surabaya.

Post G. 1987. Textbook of Fish Health. T. FH. Publicasion Inc, New York.

Jasminandar, Y. 2011. Prevalensi Parasit dan Penyakit Ikan Air Tawar yang Dibudidayakan di Kabupaten Kupang. Jurnal Ilmu-ilmu Hayati dan Fisik. 1(4): 13-16.
Rohmana, D. 2009. Konversi Limbah Budidaya Ikan Nila Menjadi Biomassa bakteri heterotrof untuk perbaikan kualitas air dan makanan udang galah, Macrobrachium rosenbergii. Institut pertanian bogor. Bogor.

Williams, L. B and E. H. Williams, Jr. 1994. Parasites of Puerto Rican Freshwater Sport Fishes. Puerto Rico Depart-ment of Natural and Environmental Resources, San Juan, PR and Department of Marine Sciences, University of Puerto Rico, Mayaguez, PR, 168 hlm.

Williams, E. H., Jr. and L.B. Williams 1996. Parasites of offshore big game fishes of Puerto Rico and the western Atlantic. Puerto Rico Department of Natural and Environmental Resources, San Juan, PR, and the University of Puerto Rico, Mayaguez, PR, $382 \mathrm{hlm}$.

Zulaeha. Hidawati., Risnawati., Ahmad Hidayat. 2012. Jenis-jenis parasit yang terdapat pada ikan payau. Universitas Muhammadiyah. Makassar 